\title{
Public Expenditures, Private Investment and Economic Growth in Togo
}

\author{
Koffi Yovo \\ University of Lome, Lome, Togo \\ Email: koffiyovo@yahoo.fr
}

How to cite this paper: Yovo, K. (2017) Public Expenditures, Private Investment and Economic Growth in Togo. Theoretical Economics Letters, 7, 193-209. https://doi.org/10.4236/tel.2017.72017

Received: November 26, 2016 Accepted: February 24, 2017 Published: February 27, 2017

Copyright $\odot 2017$ by author and Scientific Research Publishing Inc. This work is licensed under the Creative Commons Attribution International License (CC BY 4.0).

http://creativecommons.org/licenses/by/4.0/

\begin{abstract}
This paper assesses firstly the impact of the level and the composition of public expenditures on growth and secondly the link between public investment and private investment in Togo. For this purpose, a neoclassical growth model and a private investment model were estimated using Two-Stage Least Squares. The findings highlight that during the period 1980-2013, the composition of public expenditures, contrarily to the level, had significant effect on economic growth. In fact, the public consumption had a negative impact whereas public investment had a positive impact on growth. Moreover, the study finds out that increasing public expenditures involves crowding-out effect on private investment. In the light of the results, the paper invites the Togolese government to change the composition of public expenditures by giving priority to the investment with careful arbitrage between private and public expenditures.
\end{abstract}

\section{Keywords}

Public Expenditures, Private Investment, Economic Growth

\section{Introduction}

Over the past five decades, macroeconomic performance of Togo was among the worst in sub-Saharan Africa. For example, the real GDP per capita steadily fell down from 305 FCFA in 1980 to 243, 205, 199, 188, and 186 FCFA respectively in 1990, 1995, 2000, 2005 and 2008. Yet, after independence, Togo foreshadowed the hope of a booming economy with an annual average growth rate of 4.5 percent between 1960 and 1973. But from 1974, with the falling rate of real GDP growth, the economic situation has considerably deteriorated and the country has elapsed into an economic crisis beginning in 1980.

To mitigate the crisis, the government, supported by the IMF and the World Bank, implemented a structural adjustment program (SAP) which focuses on 
economic stabilization (demand side) and restructuring (supply side). Restructuring was aimed to restore production efficiency by reducing distortions that hinder it. The main measures were: liberalization of international trade, elimination of domestic price controls, public sector reform, and restructuring of the banking sector. Stabilization, in turn, would mean reducing aggregate demand to a level compatible with the level of local production and sustainable debt. This aim should be achieved through appropriate monetary and fiscal policies and adjustment of the size of the government.

Restrictive fiscal measures applied in the framework of the stabilization component have been unfortunately followed by a speeding degradation of the public goods supply in the fields of health, education, infrastructure, and social protection, all of whose detrimental consequences on the population's welfare have undermined projected growth. Similarly, renewed economic growth after devaluation in January 1994 did not translate into tangible results, such as reducing poverty, creating jobs and improving the living conditions of the total population.

Gogue and Evlo [1] have already criticized Togolese government fiscal policy for its inefficient allocation of public expenditure, which has even led to the crowding out of private enterprises during the period 1980-2000.

Banque Mondiale [2] has also criticized the government for unfavourable composition of public expenditures between consumption and investment since over the last twenty years, the ratio of consumption expenditure to GDP has varied between 1 - 25 percent against 1 - 4 percent only, the ratio of capital expenditure to GDP. This low share of investment in GDP raises questions about the effectiveness of fiscal policy as an instrument to boost growth in Togo.

However, in favour of the debt relief obtained under the HIPC initiative in 2010, public expenditures have grown rapidly. Between 2010 and 2013, public expenditures were raised sharply from 354 to 557 billion CFA, more than 100\% of increase. However this increase in public expenditures was not translated into robust growth since it involved only 1.5 points in growth (4\% to $5.5 \%$ ). These results show that the higher level of government expenditures is not the main determinant of the process of growth. In this study, it is hypothesized that other factors need to be considered including the way of financing public expenditure and arbitrage between consumption and investment. According to the above, three questions arise.

To stimulate growth, should the Togolese government increase the current level of public expenditure or reduce it? Should the government change the composition of public expenditures in order to better impact growth? What is the impact of increasing public investment on private investment?

To respond to these queries, the study assesses firstly the impact of the level and the composition of the public expenditures on growth and secondly the impact of public investment on private investment.

The remaining text is structured around four points. The second section focuses on stylized facts that relate to growth profile in Togo. The third section 
presents the literature review. The fourth section presents the research methodology and the fifth section presents the results and the discussion.

\section{The Growth Profile during 1980-2013 in Togo: Some Stylized Facts}

In describing the growth history of Togo over 1980-2013, we can distinguish four periods: 1980-1989, 1990-1999 and 2000-2009 and 2010-2013.The division of these four stages is based on the pioneer work of Gogue and Evlo (2008) who classified the episodes of growth according to prominent changes that has affected the growth in Togo. The stylized facts described below refer to Table 1 and Figure 1 which data are drawn from BCEAO database and African Development Indicators.

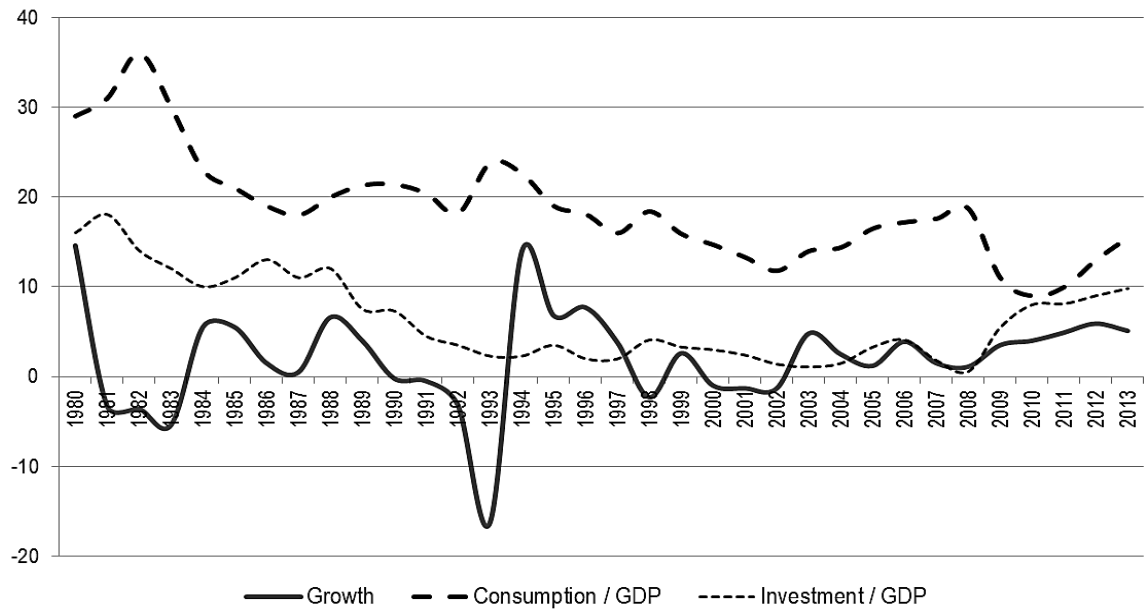

Figure 1. Public consumption, public investment and growth. Note: Figure 1 depicts the evolution of public consummation, public investment and growth over the period 1980 and 2013 which is the period covered by the study. On horizontal axis, we have the successive years and on vertical axis the ratios of public consumption/GDP, public investment/GDP and the real GDP growth.

Table 1. Evolution of macroeconomic indicators from 1980 to 2013.

\begin{tabular}{|c|c|c|c|c|c|c|c|}
\hline & $1980-1984$ & 1985-1989 & 1990-1994 & 1995-1999 & $2000-2004$ & 2005-2009 & $2010-2013$ \\
\hline Total public Expenditure/GDP (\%) & 31.84 & 28.64 & 25.26 & 20.96 & 16.79 & 20.98 & 22.15 \\
\hline Public consumption/GDP (\%) & 19.60 & 18.46 & 21.28 & 17.48 & 13.64 & 17.32 & 16.65 \\
\hline Public Investment/GDP (\%) & 12.24 & 10.18 & 3.98 & 3.48 & 3.15 & 3.66 & 5.50 \\
\hline Private Investment/GDP (\%) & 8.00 & 7.64 & 7.38 & 8.66 & 13.27 & 13.05 & 14.00 \\
\hline Total Investment/GDP (\%) & 20.24 & 17.82 & 11.16 & 12.14 & 16.42 & 16.71 & 19.50 \\
\hline Budget deficit/GDP (\%) & 6.80 & 2.40 & 8.20 & 5.28 & 0.94 & 4.10 & 3.54 \\
\hline Current account deficit/GDP (\%) & 6.40 & 4.72 & 7.00 & 9.10 & 10.10 & 14.30 & 6.3 \\
\hline Public Debt/GDP (\%) & 109.80 & 119.20 & 96.40 & 98.60 & 100.60 & 80.50 & 40.35 \\
\hline Inflation (\%) & 9.82 & 0.26 & 8.08 & 5.34 & 1.68 & 4.56 & 2.9 \\
\hline Real growth (\%) & 1.56 & 3.62 & -1.26 & 3.72 & 0.74 & 1.64 & 4.80 \\
\hline
\end{tabular}

Source: Author's calculation based on data from BCEAO and ADI (African Development Indicators). 


\section{Economic Growth 1980-1989: Economic Reform}

This period can be regarded as a period of economic reforms. Indeed, in the early 1980s, the main macroeconomic indicators have shown a serious deterioration of the economic situation. External debt rose to $110 \%$ of GDP in the first half of the period. The budget deficit and current account deficit of balance of payments which reached significant levels in the first half of the period are respectively $6.80 \%$ and $6.40 \%$. During this period, the Togolese economy has been adversely affected by many factors: the second oil shock, falling phosphate prices, rising dollar and interest rates, and the severe drought that has marked the year 1981.

To face this situation, the government has implemented a Structural Adjustment Program (SAP). Thus a package of stabilization and adjustment was developed by the government and supported by a series of agreements with the IMF and sectorial adjustment loans from the World Bank. To cut public expenses, the government was compelled to freeze recruitment and promotion of civil servants. These measures have helped reduce the public consumption, the budget deficit and the current account deficit of $1 \%, 4 \%$ and $2 \%$ respectively.

\section{Economic Growth 1990-1999: Political Crisis and On-Going Reform}

The period of 1990-1999 can be divided into two sub-periods: 1990-1994 and 1995-1999. The sub-period 1990-1994 can be seen as a period of Togolese struggle for democracy. During this period, most of the macroeconomic indicators have shown a serious deterioration. Public investment fell sharply (77\%). The budget deficit and current account deficit rose respectively to $241 \%$ and $48 \%$ and the inflation reached $8 \%$. This bad performance is explained by the fact that the democratization process in Togo has been particularly marked by social and political trouble that peaked between 1992-1993 with a general strike for nine months, causing a deterioration of the economic situation which was exacerbated by the suspension of cooperation of EU and other development partners. Consequently, the economy experienced a recession because of the drastic decline in private investment resulting from the reduction of domestic savings and the inability of the government to attract Foreign Direct Investment (FDI). Therefore, from 1992 to 1993, the growth rate of GDP per capita passed from $-5.9 \%$ to $-17.4 \%$. This annual rate which is the worst during the three periods is, in a large measure, explained by the nine months strike that paralyzed the overall production system.

In 1994 came the devaluation of 50\% of CFA franc. This change of currency parity did not put the economy onto sustainable growth path due to its weak competitiveness and the low adaptability of the productive system. In fact, the growth of real GDP increased from -17\% (1993) to 13.9\% (1994). However, this increase of growth lasted only for two years (from 1994 to 1996).

The second period from 1995 to 1999 can be seen as the on-going reforms initiated in the previous period as part of SAPs. Those reforms continued through the following lines:

-Reform of customs and financial sector; 
-Price and trade liberalization and adherence of Togo to WTO in 1995;

-Removal of state monopoly (suppression of OPAT), and privatization of public enterprises.

\section{Economic Growth 2000-2009: Emergence of Private Sector}

The period 2000-2009 is clearly characterized by the emergence of the private sector and the resumption of cooperation in 2005. Indeed, in the first half of the period, the private investment increased from $8.66 \%$ to $13.27 \%$ of GDP, an increase of $53 \%$. However, the public investment has stagnated between $3 \%$ and $4 \%$ of GDP. During the entire period the budget deficit and current account deficit did not respect the convergence criteria of WAEMU. They rose respectively from $0.94 \%$ to $4.10 \%$ and $10 \%$ to $14 \%$ between the $2000-2004$ and $2005-2009$. The gradual deterioration of the current account is driven mainly by the deterioration of the trade balance in connection with the depression observed in export activities. Therefore, although private investment has rebounded significantly, growth remained soft (less than 2\%) despite the average level of inflation which is close to the union standard of $3 \%$. This shows that the rate of public investment which has been stabilized at between 3\% - 4\% of GDP was insufficient to boost growth of the Togolese economy.

\section{Economic Growth 2010-2013: Increase of Public Investment}

The period 2010-2013 appears as the period of renewed growth. GDP growth increased from $4 \%$ in 2010 to $5.1 \%$ in 2013 . This improvement is due to a relatively low inflation (2.9\%), a rapid increase in public expenditure and especially an improvement of their allocation. Indeed, between 2005-2009 and 2010-2013 the public investment ratio increased from 3.66 to 5.5 and the consumption expenditures had fallen from 17.32 à 16.65 . This reallocation of the public expenditures and the sustainability of private growth seemed to have stimulated the economic growth observed in the period. In the same vein, fiscal and current account deficits have also been improved.

\section{Literature Review}

A large review of economic literature establishes the link between public expenditure and economic growth. Here, we examine this link through theoretical and empirical approaches.

\subsection{Theoretical Approach}

Theoretical discussions about the link between public expenditure and economic growth are based upon the old and controversial debate on the role of the government in the economy. In general, this debate is divided between two main theses. The first argues that public expenditures are a powerful instrument of economic growth. The second claims that public expenditure has, in all the cases, a harmful effect on growth. The first thesis, which is the Keynesian view, considers that the regulation of economic activity by government passes through countercyclical actions.

This perspective leads governments to actively support the agent activities when 
demand is depressed and to slow it down when economic activities accelerating brings fears about internal and external disequilibrium. Thus, in the short term, public spending can be used to stimulate aggregate demand and boost economic growth. The argument in favour of public spending is that some public expenditures, especially public investment, such as roads, electricity, transportation, telecommunications, education and health, generate externalities that enhance productivity of private factors and can thus support economic growth (Blejer and Khan [3], Aschauer [4], Tanzi and Zee [5]).

The second thesis of neoclassical view contests the Keynesian multiplier effect and argues that the expansionary fiscal policy has no positive effect on the economic activity. The recovery policies by government spending may even have depressive effects on the economy mainly because of crowding-out effects they exert on investment and private consumption. As a result, these negative effects influence economic agents' anticipation of future consequences of fiscal policy, and lead them to adjust their behaviour accordingly to consumption and savings (Barro [6]).

In fact, the effect of public spending on growth depends on the source of funds used by the government. If these expenditures are financed by higher direct taxes, the net impact on growth may be negative despite a positive effect on the marginal productivity of private capital. If the expenditures are financed by borrowing, then the economic agents, who reason over a long period, understand that the non-taxation of today is a deferral of tax in the future. Consequently, instead of increasing their level of consumption, they save the extra income due to the non-taxation of today, to pay future taxes, which tends to reduce demand. Increased public spending is offset by lower private demand and fiscal policy is thereby reduced. This is known as the theory of Ricardian equivalence.

This thesis based on the assumption that public spending reduces private investment is the main argument of the defenders of the existence of negative relationship between public spending and economic growth. Nevertheless, other arguments, even though, subsidiary are mentioned. Ram [7] argues that: 1) in the absence of competition and profit motivation, the government generally operates in a non-efficient environment, 2) the government regulatory action causes constraints and excessive additional costs in the economic system, and 3) monetary and fiscal policies of the government create economic distortions and reduce the productivity of the system.

It is further argued that public spending does not necessarily reflect the exact level of agents' preference since the public decisions do not result exclusively from the aggregation of individual preferences. Politicians aim to maximize their chances of re-election, thus their behaviour may not reflect an equilibrium which is not determined solely by the level of the median voter but mostly by the self-interest games of lobbies and bureaucrats (Mills and Quinet [8]). This negative perception of public spending on economic growth is based on the assumption that markets are not always efficient. Thus, public investments, determined 
arbitrarily, are not efficient when compared to private investment. On the basis of this low productivity of public investment, any increase in public spending will slow down the overall economic growth, hinder the accumulation of physical and human capital and reduce the speed of innovation in the private sector (Diamond [9]).

\subsection{Empirical Approach}

As in the case of theoretical developments, unanimity is not made on the exact nature of the relationship between public spending and economic growth particularly in developing countries. The controversy which is highlighted in the theory is still present in the empirical investigation.

In regards to the effect of the level of total expenditure, though a consensus seems to be reached regarding the positive impact of public spending on growth in OECD countries (Ghali [10]), the fact varies across developing countries. Indeed, while Cheng and Lai [11] found that public expenditures have a positive impact on economic growth in South Korea, Ojo and Oshikoya [12] have shown in the case of sub-Saharan African countries, that an expansionary fiscal policy reduces growth in per capita GDP of these countries. This result is consistent with that of Ghura and Hadjimichael [13]. Similarly, Tenou [14] who estimate with the panel data the determinants of growth in WAEMU countries also obtained the same result. However, Nubukpo [15], found no significant relationship between public spending and economic growth for most WAEMU countries.

The empirical literature on the effects of the composition of expenditure has also produced controversial results. Testing a sample of 87 countries, including 25 countries in Sub-Saharan Africa, Veganzones [16] showed a positive impact of public investment in infrastructure on growth and a complementary relationship between public and private investment. Knight, Loayzan and Villanueva [17] and Nelson and Singh [18] have also revealed a significant effect of public infrastructure investment on growth using a sample of developing countries, particularly significant during the 1980s. Easterly, Loayzan, Montiel and Rebelo [19] reached the same result by considering public investment in transport and communication. However, Khan and Kumar [20], using a sample of 95 developing countries during the period 1970-90, showed that the effects of private and public investment on growth were significantly different, with private investment being consistently more productive than public investment.

Moreover, the impact of public spending has been oriented mainly to explore the differential impact between public investment and public consumption. Gupta, Clements, Baldacci, and Mulas-Granados [21] showed, using a sample of 39 lowincome countries that countries where public expenditures are dominated by salaries tend to have lower growth rates, while those who emphasize capital expenditures, experience more rapid growth when the costs are associated with a modest deficit. In the WAEMU countries, Nubukpo [15] also highlighted the negative effect of public consumption expenditure on growth in the short and 
long-term and the long-term positive impact of public investment spending on growth economies of the WAEMU. The negative effects of public consumption have also been obtained by Barro [22].

In contrast, Devarajean, Swaroop and Zou [23], showed a positive relationship between spending on public consumption (measured in current expenditure as a percentage of total expenditure) and economic growth and an inverse relationship between the latter and public investment. This result, according to the authors, is explained by a misallocation of fiscal resources for capital expenditure (to the detriment of infrastructure maintenance costs). Ghosh and Gregoriou [24] obtained similar results for 15 developing countries.

Discrepancies remain when comparing the effects of capital expenditures to the effects of consumption expenditures in industrialized countries. For example, Perotti [25] showed that in contrary to a common opinion, there is no evidence that government investment shocks are more effective than government consumption shocks in boosting GDP. For him the multiplier of the investment is not greater than the multiplier of consumption in four European countries whereas Straub and Tchakarov [26] find that investment multipliers are more than the consumption expenditure multipliers in 12 European countries. The latter showed that the increase in investment spending, in general, generates multipliers greater than the increase in consumption spending, because increased capital expenditure not only increases the aggregate demand but also aggregate supply through an increase in aggregate production and improvement of the marginal productivity of labour and private capital.

Despite the inconclusive nature of the empirical literature, the emerging consensus view, however, accepts that changes in the composition of public spending on capital expenditures (health, education and infrastructure base) tend to have a positive impact on growth.

\section{Methodology}

\subsection{Starting Point}

The starting point is the neoclassical growth model of Solow who hypothesized that output depends on capital and labour inputs. It is formulated as follows:

$$
y=g(K, L)
$$

where: $y$ stands for growth of real GDP, K stands for growth of capital and L stands for growth of labour.

The model is referenced to the extension of Solow model like developed by Barro [22] and Aschauer [4] and used by Khan and Kumar [21] among others in the literature. In this study, it is hypothesized that output growth depends on the investment used for the capital stock and on the labour force. So, the Equation (1), in linear form is rewritten as follows:

$$
y=a_{0}+\alpha_{1}\left(\frac{I}{y}\right)+a_{2} L
$$

where $a_{1}>0 ; a_{2}>0$ and I/y represents the ratio of total Investment to GDP. 


\subsection{Expanded Model}

\subsubsection{Linear Model}

The expanded form of Equation (2) is specified by expressing growth (y) as a function of private investment (Invpri), public investment (Invpu), public consumption (Conspu, inflation (Inf), index of terms of trade (TOT) and the labor force (Lab). The Term of trade (TOT) is included in the model to account for the fact that Togo is a small open economy. Finally, real GDP lagged by one period is included in the model to improve the quality of prediction. The model to be estimated is formulated as follows:

- Impact of the level:

$$
y_{t}=\alpha_{0}+\alpha_{1} \operatorname{Gdp}_{t-1}+\alpha_{2} \operatorname{Invpri}_{t}+\alpha_{3} \operatorname{Exp}_{t}+\alpha_{4} \operatorname{Tot}_{t}+\alpha_{5} \operatorname{Lab}_{t}+\varepsilon_{t}
$$

\section{- Impact of the composition:}

$$
y_{t}=\alpha_{0}+\alpha_{1} \mathrm{Gdp}_{t-1}+\alpha_{2} \text { Invpri }_{t}+\alpha_{3} \operatorname{Invpu}_{t}+\alpha_{4} \mathrm{Conspu}_{t}+\alpha_{5} \operatorname{Tot}_{t}+\alpha_{6} \mathrm{Lab}_{t}+\varepsilon_{t}
$$

Definition of the variables:

$y_{t}$ : is the growth of real GDP;

$\mathrm{Gdp}_{t-1}$ : is the GDP of the previous year;

Invpri $_{t}$ : is the private investment to GDP;

$\mathrm{Invpu}_{t}$ : is the public investment to GDP;

$\mathrm{Conspu}_{t}$ : is the public consumption to GDP;

$\mathrm{Lab}_{t}$ : is the labor force;

Tot $_{t}$ : is the term of trade index.

\subsubsection{Nonlinear Model}

Since Barro [22], it is known that growth is not actually a linear function of public spending. For example, Devarajean, Swaroop and Zou [23] showed that the share of productive expenditure in the budget can have a positive effect on growth if it is low, and a negative effect if it is high, suggesting a curve having an upward and downward sloping. For this purpose, we extend the model by including in the initial Equation (3) the square of total public expenditure and in the Equation (4) the square of public consumption and the square of public investment. Therefore Equations (3) and (4) become:

$$
\begin{aligned}
y_{t}=\beta_{0}+\beta_{1} \mathrm{Gdp}_{t-1}+\beta_{2} \operatorname{Invpri}_{t}+\beta_{3} \operatorname{Exp}_{t}+\beta_{4} \operatorname{Exp}_{t}^{2}+\beta_{5} \operatorname{Tot}_{t}+\beta_{6} \mathrm{Lab}_{t}+\gamma_{t} \\
y_{t}=\theta_{0}+\theta_{1} \mathrm{Gdp}_{t-1}+\theta_{2} \operatorname{Invpri}_{t}+\theta_{3} \operatorname{Invpu}_{t}+\theta_{4} \operatorname{Conspu}_{t} \\
+\theta_{5} \operatorname{Invpu}_{t}^{2}+\theta_{6} \operatorname{Conspu}_{t}^{2}+\theta_{7} \operatorname{Tot}_{t}+\theta_{8} \mathrm{Lab}_{t}+\delta_{t}
\end{aligned}
$$

\subsection{Private Investment Model}

Finally, in the process, it was necessary to establish a relationship between private investment and public investment. In this perspective, private investment is expressed as a function of public investment (Invpu), public consumption expenditure (Conspu) and a number of control variables namely, the real GDP growth $\left(y_{t}\right)$, credit to the private sector $\left(\mathrm{Cred}_{t}\right)$ and inflation $\left(\operatorname{Infl}_{t}\right)$. These variables are deemed relevant for the model in reference to Abou [27] and Khan and Kumar [20]. So, the inclusion of public investment and public consumption 
expenditures allowed testing crowding-out effect between private investment and public expenditures. The variable credit is included in the model because in developing economies, private investment is often constraint by availability of bank credit. Concerning the inflation, when it is high, central Bank will raise interest rate and the increase of credit cost will decrease private investment. Finally, it is expected that GDP growth included in the model has positive effect in private investment because growth raises aggregated demand which in turn affects positively private investment.

In light of the above, we can identify two endogenous variables; GDP growth and private investment.

This leads to two simultaneous equations which the first is the growth Equation (4) and the second the private investment Equation (7) which is expressed as follows:

$$
\text { Invpri }_{t}=\beta_{0}+\beta_{1} \text { Invpu }_{t}+\beta_{2} \text { Conspu }_{t}+\beta_{3} y_{t}+\beta_{4} \operatorname{Cred}_{t}+\beta_{5} \operatorname{Infl}_{t}+\mu_{t}
$$

Equations (4) and (7) are well identified as three variables $\mathrm{Gdp}_{t-1}, \mathrm{Lab}_{t}$ and $\mathrm{Tot}_{t}$ in Equations (3) or (4) does not appear in Equation (7) and two variables Cred $_{t}$ and Infl $_{t}$ in Equation (7) are not included in the Equations (3) or (4). These variables are used as instrumental variables.

\subsection{Model Estimation and Data}

The two models, the growth model and the private investment model are both estimated by Two-Stage Least Squares Instrumental Variables regression (TSLSIV). Estimations are made by using instrumental variables aforementioned. The linear growth model is first estimated to appreciate the level and the composition effect of the public expenditures on growth. Then the non-linear model is estimated by the same method to capture the level of maximum consumption and minimum investment required to boost growth. The data used are annual series covering the period of 1980-2013. They are drawn from BCEAO database and African Development Indicators. The estimation of the models is done by using STATA 14 software.

\section{Empirical Results}

\subsection{Effect of the Level and the Composition of Public Expenditures on Growth}

-Results with Two-Stage Least Squares Instrumental Variables (TSLS-IV) estimations of equations (3) and (4) are reported in Table 2. In column (1), results express the growth model with the total public expenditures. In column (2), the total public expenditures are split into public consumption and public investment. The analysis of the results brings out the fact that the estimated models are robust. Adjusted $\mathrm{R}^{2}$ and F-statistics are weak but are on acceptable levels. The models do not suffer the problem of autocorrelation. Among the 5 explanatory variables introduced into Equation (3), three variables are significant. There are GDP $(-1)$, term of trade and population. In the disaggregated model (Equation (4)), four variables have a significant effect. 
Table 2. Estimation results of the linear growth model.

\begin{tabular}{ccc}
\hline Real Growth & $\begin{array}{c}\text { Model (3) coefficients } \\
\text { (Level effect) }\end{array}$ & $\begin{array}{c}\text { Model (4) coefficients } \\
\text { (Composition effect) }\end{array}$ \\
\hline GDPreal (-1) & $-0.08^{* *}$ & 0.009 \\
Public Expenditures & -0.06 & $(0.00)$ \\
Public Consumption & $(-0.19)$ & - \\
Public investment & - & $-0.60^{*}$ \\
& - & $(-1.78)$ \\
Private Investment & 0.67 & $0.03^{* *}$ \\
& $(1.34)$ & $(2.20)$ \\
Population & $2.37^{* *}$ & 0.59 \\
Term of trade & $(2.44)$ & $(1.26)$ \\
& $0.17^{*}$ & $8.26^{* * *}$ \\
Constant & $(1.94)$ & $(3.84)$ \\
R & -24.12 & 0.10 \\
DW & $(-0.25)$ & $(1.25)$ \\
F(.) & 30 & -13.95 \\
Number of observations & 4.05 & $(-0.46)$ \\
\hline
\end{tabular}

Source: Author's calculation based on data from BCEAO and ADI (African Development Indicators). Values in parenthesis are t-statistics. ${ }^{*}=$ significant at $10 \%,{ }^{* *}=$ significant at $5 \%,{ }^{* *}=$ significant at $1 \%$. Model 3 expresses the growth model with public expenditures. In model 4 , public expenditures are split into public consumption and public investment.

-According to these results, the total public expenditures variable does not have any significant positive externality effect on growth. This result tends to corroborate earlier findings by Nubukpo [15] for the WAEMU countries. This absence of Keynesian effect of the total public expenditure raises the concerns about the effectiveness of the increase of the public expenditures amount. Moreover, by investigating differential impact of public consumption and public investment, results in column (2), show a negative and significant effect of public consumption and positive effect of public investment on growth. These results involve some interpretations. First, the negative effect of public consumption is not in line with Devarajan Swaroop and Zou [23] but is consistent with the findings of Tanzi and Zee [5], Tenou [14], and Nubukpo [15]. The latter found that in most WAEMU countries, particularly in Togo, public consumption has a negative effect on growth. How can we explain this result in the Togolese context? A priori, the public consumption as a demand component should cause, by the means of the Keynesian multiplier effect, a growth of the GDP. Nevertheless, in an open economy, the impact of the multiplier effect on the growth is even lower since the economy's marginal propensity to import is high. This could explain, given the profile of Togo as net importer of consumption goods, the overall negative impact of the public consumption on the growth. 
Public consumption, here, includes wages, transfers, subsidies, and expenditure on goods and basic services that ensure the daily functioning of public administration. They do not necessarily fit in a growth target. They correspond to what some authors called unproductive expenditures. Thus, a misallocation of these expenditures especially that is in favour of transfers and subsidies could have an adverse effect on growth. Finally, it is not excluded that the prominence given to consumption over investment expenditures can also harm growth.

-In contrast, investment expenditures have a significantly positive impact on growth. This result tends to corroborate the results of most studies in connection with the impact of public investment on growth. However, the mitigated impact of public investment on growth raises questions about the effective destination of the expenditure engaged by government. Either the public investments were used to finance not very productive projects in terms of contribution to the economic growth, or they were diverted from their initial destination. This raises in either case the issue of good governance. Nevertheless, the relatively low level of investment (between 3\% and $4 \%$ of the GDP) could also have contributed to limit its effectiveness.

Unfortunately, private investment has no effect on growth, probably due to crowding effect on the private sector during the period between the 1980s and 2000s (Gogue and Evlo [1]). Indeed, during this period, private investment has remained low. The raising of the level of private investment is a relatively recent phenomenon in the Togolese economy.

\subsection{Optimal Level of Public Expenditures and Its Impact on Growth}

To determine the threshold values of consumption and investment, a non-linear model is estimated. Following Barro [22] and Devarajan, Swaroop and Zou [23], the squared value of public expenditures are included in the linear model to have the non-linear form. The results are reported in Table 3.

By considering, model (5), Table 3 shows that, in contrast to the results of the linear specification, total public expenditure has a negative coefficient with a positive and significant coefficient of the square. The behaviour of this variable suggests that the non-linear specification is better than the linear one.

In Model (6), the variables public consumption, public investment shows the same trend. The coefficient of public consumption which has negative sign in the linear specification becomes positive and the coefficient of the square in the non-linear specification is negative and significant. The coefficients of public investment with positive sign in the linear specification become negative in the non-linear specification with the coefficients of square positive and significant. Again, this behaviour simply reflects the fact that the non-linear form is the most appropriate specification of the growth model.

The change of the signs merely reflects the existence of a curve with two phases: an upward and a downward sloping. Thus, the negative sign displayed by the coefficient on consumption in the non-linear specification simply shows that 
Table 3. Results of the estimation of non-linear model.

\begin{tabular}{|c|c|c|}
\hline Real Growth & $\begin{array}{l}\text { model (5) coefficients } \\
\text { (Level effect) }\end{array}$ & $\begin{array}{c}\text { model (6) coefficients } \\
\text { (Composition effect) }\end{array}$ \\
\hline GDP real $(-1)$ & $\begin{array}{l}-0.01^{* * *} \\
(-4.48)\end{array}$ & $\begin{array}{l}-0.03^{* * *} \\
(-4.20)\end{array}$ \\
\hline Public Expenditures & $\begin{array}{l}-3.51 \\
(-1.45)\end{array}$ & - \\
\hline Public Expenditures squared & $\begin{array}{l}0.06^{*} \\
(1.81)\end{array}$ & - \\
\hline Public Consumption & - & $\begin{array}{l}3.58^{* *} \\
(2.27)\end{array}$ \\
\hline Public consumption squared & - & $\begin{array}{l}-0.11^{\star *} \\
(-2.44)\end{array}$ \\
\hline Public investment & - & $\begin{array}{l}-0.80 \\
(-1.40)\end{array}$ \\
\hline Public Investment squared & - & $\begin{array}{l}0.70^{* *} \\
(1.97)\end{array}$ \\
\hline Private investment & $\begin{array}{c}2.33 \\
(0.90)\end{array}$ & $\begin{array}{c}0.61 \\
(0.42)\end{array}$ \\
\hline Population & $\begin{array}{l}1.05 \\
(0.73)\end{array}$ & $\begin{array}{c}0.78 \\
(0.35)\end{array}$ \\
\hline Term of trade & $\begin{array}{c}0.22 \\
(1.07)\end{array}$ & $\begin{array}{c}0.03 \\
(0.40)\end{array}$ \\
\hline Constant & $\begin{array}{l}-6.12 \\
(0.54)\end{array}$ & $\begin{array}{l}-7.40 \\
(-0.34)\end{array}$ \\
\hline Number of observations & 30 & 30 \\
\hline $\mathrm{F}(.)$. & 5.12 & 5.46 \\
\hline $\mathrm{R}^{2} \mathrm{Adj}$ & 0.37 & 0.58 \\
\hline DW & 2.05 & 2.65 \\
\hline
\end{tabular}

Source: Author calculation with data from BCEAO and ADI (African development Indicators. ${ }^{*} p<0.1 ;{ }^{* *} p$ $<0.05 ;{ }^{* * *} p<0.01$.

data points cluster along the downward sloping part of the curve. The function reaches its maximum when the ratio of consumption/GDP is around $16 \%$. That is the maximum level beyond which the public consumption which is essential to the functioning of government, become harmful to economic growth. Similarly, we can estimate to $5.7 \%$ per GDP, the minimum level of public investment needed to boost growth in Togo.

\subsection{Relationship between Private Investment and Public Investment}

A surprising result from the above estimates is that public investment has a significant positive effect on growth while private investment has no significant effect on growth. Is there a crowding-out effect or simply a strong correlation between private investment and public investment which probably picked up the effect of the first? To answer these questions, we firstly test the correlation between variables in the model. The Spearman correlation test gives the results shown in Table 4. 
Table 4. Correlation coefficients between variables.

\begin{tabular}{|c|c|c|c|c|c|c|}
\hline & $\begin{array}{c}\text { Public } \\
\text { Expenditure }\end{array}$ & $\begin{array}{c}\text { Public } \\
\text { Consumption }\end{array}$ & $\begin{array}{c}\text { Public } \\
\text { Investment }\end{array}$ & $\begin{array}{c}\text { Private } \\
\text { Investment }\end{array}$ & $\begin{array}{l}\text { Term of } \\
\text { Trade }\end{array}$ & Population \\
\hline $\begin{array}{c}\text { Public } \\
\text { Expenditure }\end{array}$ & 1.00 & & & & & \\
\hline $\begin{array}{c}\text { Public } \\
\text { Consumption }\end{array}$ & 0.68 & 1.00 & & & & \\
\hline $\begin{array}{c}\text { Public } \\
\text { Investment }\end{array}$ & 0.85 & 0.23 & 1.00 & & & \\
\hline $\begin{array}{c}\text { Private } \\
\text { Investment }\end{array}$ & -0.62 & -0.54 & -0.23 & 1.00 & & \\
\hline Term of Trade & 0.28 & 0.15 & 0.34 & 0.07 & 1.00 & \\
\hline Population & -0.48 & -0.65 & -0.41 & 0.31 & -0.12 & 1.00 \\
\hline
\end{tabular}

Source: Author's calculation based on data from BCEAO and ADI (African Development Indicators).

Table 4 shows that the variables private investment and public investment are fairly correlated with each other. This allows us to proceed econometric testing of the relationship. Following Abou [27], khan and Kumar [20], we try to explain private investment (dependent variable) with public investment and other variables like expressed by the Equation (7). The results are reported in Table 5.

It appears that a $10 \%$ increase in public investment leads to a decrease in private investment of $2.2 \%$ showing that there is a crowding-out effect of public investment on private investment. Similarly, a $10 \%$ increase in public consumption involves a decrease in private investment of $5.6 \%$. The crowding out effect of public expenditures can be explained by the financing of public investment (infrastructures, education and health) and consumption through taxes increase or by mobilizing of domestic saving. This result is not in line with Abou [27] who found a complementary effect between public and private investment for the period 1970-2003. However, it corroborates the findings of Gogue and Evlo [1] who showed that during the period 1980-2000 most enterprises in Togo were crowded out. The discrepancy between the results is not ambiguous since they are related to different periods, while fiscal policy has evolved over time. Moreover, the credit to economy seems to not finance effectively private investments.

\section{Conclusion and Policy Implications}

This paper attempts to answer three questions of economic policy. In order to stimulate the growth in Togo, should the government increase or reduce the current level of public expenditures? To better impact growth, should the government change the composition of public expenditures? What is the impact of public expenditures increase on private investment? To answer these queries, a neoclassical growth model was estimated using Two-Stage Least Squares. The estimation of growth models has brought out the fact that the public expenditures over the period between 1980 and 2013 did not have a significant positive effect on the economic growth. Meanwhile, public consumption expenditures had a negative impact and investment expenditures have a positive impact on growth. 
Table 5. Relationship between private investment and public investment.

\begin{tabular}{cc}
\hline Dependent Variable: Private investment & Coefficients \\
\hline Growth & -0.01 \\
& $(-0.01)$ \\
Public consumption & $-0.56^{* *}$ \\
Public investment & $(-2.78)$ \\
& $-0.22^{* *}$ \\
Inflation & $(-2.23)$ \\
& 0.04 \\
Credit & $(0.54)$ \\
& 0.16 \\
Constant & $(0.38)$ \\
Observations Number & $9.20^{* *}$ \\
F (.) & $(2.20)$ \\
$\mathrm{R}^{2}$ Adj & 30 \\
DW & 4.22 \\
\hline
\end{tabular}

Source: Author's calculation based on data from BCEAO and ADI (African Development Indicators). ${ }^{*} p<$ $0.1 ;{ }^{* *} p<0.05 ;{ }^{* * *} p<0.01$.

The absence of Keynesian effect of the public expenditure raises the issue of the effectiveness of these expenditures and advocates for a sound and rigorous management of public finances. But it would be inappropriate to reduce drastically the current level of public expenditure. Indeed, public expenditures remain vital for the financing of the economy and the fight against poverty. What the results seem to suggest is the change of the current composition of public expenditures. Indeed, the main lesson of this study is that public expenditures tend to support growth when they are prioritized for investment, but are also likely to slow it down when privilege is given to consumption. So it is advisable, in the light of the results, to decrease the consumption in favour of investment. The mitigated impact of public investment on growth raises concerns about the effective destination of the expenditure engaged by government. Either the public investments were used to finance not very productive projects in terms of contribution to the economic growth or they were diverted from their initial destination. This reality raises in either case the issue of good governance of productive resources.

Moreover, the study highlights that the way the public expenditures are financed plays a crucial role in determining the impact of public expenditure on growth. Indeed, the optimal allocation of total expenditures (both public and private) is vital for achieving sustainable growth in Togo. This allocation involves a careful arbitrage between both private and public expenditures. The results show that this arbitrage involves crowding out effect of the private sector suggesting the necessity to review the way of financing public expenditures, in particular, the mobilization of domestic saving, the money creation and the increase of tax revenue. 


\section{Acknowledgements}

I thank the Editor and the referee for their comments. I am also grateful to African Economic Research Consortium (AERC) for funding this research and to a number of people who provided helpful comments at the various AERC Biannual Research Workshops, particularly Mohsin Khan, and Steve O'Connell, resource persons in group B. Nonetheless, I am solely responsible for any errors and omissions in this study.

\section{References}

[1] Gogué, T.A. and Evlo, K. (2008) Anti-Growth Syndromes in Africa: Togo: 19741989. In: Ndulu, B.J., O’connell, S.A., Azam, J.P., Bates, R., Collier, P. and Soludo, C., Eds., The Political Economy of Economic Growth in Africa 1960-2000, Cambridge University Press, Cambridge, Vol. 1, 150-157.

[2] Banque Mondiale (2010) Revue des dépenses publiques. Mission Résidente de la Banque Mondiale au Togo, Togo, Vol. 1.

[3] Blejer, M. and Khan, M. (1984) Government Policy and Private Investment in Developing Countries. IMF Staff Papers, 31, 379-403. https://doi.org/10.2307/3866797

[4] Aschauer, D.A. (1989) Is Public Expenditure Productive? Journal of Monetary Economics, 23, 177-200. https://doi.org/10.1016/0304-3932(89)90047-0

[5] Tanzi, V. and Zee, H. (1997) Fiscal Policy and Long-Run Growth. IMF Staff Papers, 44, 179-209. https://doi.org/10.2307/3867542

[6] Barro, R. (1990) Government Spending in a Simple Model of Endogenous Growth. Journal of Political Economy, 98, 103-125. https://doi.org/10.1086/261726

[7] Ram, R. (1986) Government Size and Economic Growth: A New Framework and Some Evidences from Cross-Sectional and Times Series Data. American Economic Review, 76, 191-203.

[8] Mills, P. and Quinet, A. (1992) Dépenses publiques et croissance. Revue Française d'Economie, 17, 29-60. https://doi.org/10.3406/rfeco.1992.1314

[9] Diamond, J. (1989) Government Expenditure and Economic Growth: An Empirical Investigation. IMF Working Paper, WP-89-45.

[10] Ghali, K.H. (1999) Government Size and Economic Growth: Evidence from a Multivariate Cointegration Analysis. Applied Economics, 31, 975-987.

https://doi.org/10.1080/000368499323698

[11] Cheng, B.S. and Lai, T. (1997) Government Expenditures and Economic Growth in South Korea: AVAR Approach. Journal of Economic Development, 22, 11-24.

[12] Ojo, O. and Oshikoya, T. (1995) Determinants of Long Term Growth: Some African Results. Journal of African Economies, 4, 163-191.

[13] Ghura, D. and Hadjimichael, M. (1996) Growth in Sub-Saharan Africa. IMF Staff Papers, 43, 605-631. https://doi.org/10.2307/3867556

[14] Tenou, K. (1999) Les déterminants de la croissance à long terme dans les pays de l'UEMOA. Notes d'Information et Statistiques. Etudes et Recherches, No. 493, BCEAO.

[15] Nubukpo, K. (2007) Dépenses publiques et croissance des Economies de l'UEMOA. Afrique Contemporaine, 200, 223-250. https://doi.org/10.3917/afco.222.0223

[16] Véganzonès, M.A. (2001) Infrastructures, Investissementet Croissance: Unbil and Edixannées Derecherches. Revue d’ Économie du Développement, 4, 31-46.

[17] Knight, M., Loayzan, N. and Villanueva, D. (1993) Testing the Neoclassical Theory 
of Economic Growth. IMF Staff Papers, 40, 512-541. https://doi.org/10.2307/3867446

[18] Nelson, M. and Singh, R. (1994) The Deficit-Growth Connection: Some Recent Evidence from Developing Countries. Economic Development and Cultural Change, 43, 167-191. https://doi.org/10.1086/452140

[19] Easterly, W., Loayzan, N. and Montiel, P. (1997) Has Latin America's Post Reform Growth Been Disappointing? Journal of International Economics, 43, 287-311. https://doi.org/10.1016/S0022-1996(97)00004-4

[20] Khan, M. and Kumar, M. (1997) Public and Private Investment and the Growth Process in Developing Countries. Oxford Bulletin of Economics and Statistics, 59, 69-88. https://doi.org/10.1111/1468-0084.00050

[21] Gupta, S., Clements, B., Baldacci, E. and Mulas-Granados, C. (2005) Fiscal Policy, Expenditure Composition and Growth in Low-Income Countries. Journal of International Money and Finance, 24, 441-463. https://doi.org/10.1016/j.jimonfin.2005.01.004

[22] Barro, R. (1997) Determinants of Economic Growth. MIT Press, Cambridge.

[23] Devarajan, S., Swaroop, V. and Zou, H. (1996) The Composition of Public Expenditure and Economic Growth. Journal of Monetary Economics, 37, 318-344. https://doi.org/10.1016/S0304-3932(96)90039-2

[24] Ghosh, S. and Gregoriou, A. (2008) The Composition of Public Spending and Growth: Is Current or Capital Spending Better? Oxford Economic Paper, 60, 484516. https://doi.org/10.1093/oep/gpn005

[25] Perotti, R. (2004) Public Investment: Another (Different) Look. WPS 2977, IGIER, Bocconi University, Bocconi.

[26] Straub, R. and Tchakarov, I. (2007) Assessing the Impact of a Change in the Composition of Public Spending. A DSGE Approach. European Central Bank, WPS 795.

[27] Abou, B.N. (2007) Structure des dépenses publiques. Investissement privé et croissance économique dans les pays de l'UEMOA. Document d'Etude et de Recherche. No. DER/07/04, BCEAO.

\section{Submit or recommend next manuscript to SCIRP and we will provide best service for you:}

Accepting pre-submission inquiries through Email, Facebook, LinkedIn, Twitter, etc. A wide selection of journals (inclusive of 9 subjects, more than 200 journals) Providing 24-hour high-quality service User-friendly online submission system Fair and swift peer-review system Efficient typesetting and proofreading procedure Display of the result of downloads and visits, as well as the number of cited articles Maximum dissemination of your research work

Submit your manuscript at: http://papersubmission.scirp.org/ Or contact tel@scirp.org 